\title{
Poverty dynamics in eight countries *
}

\author{
Greg J. Duncan ${ }^{1}$, Björn Gustafsson ${ }^{2}$, Richard Hauser ${ }^{3}$, Günther Schmauss ${ }^{4}$, \\ Hans Messinger ${ }^{5}$, Ruud Muffels ${ }^{6}$, Brian Nolan ${ }^{7}$, and Jean-Claude Ray ${ }^{8}$ \\ ${ }^{1}$ Survey Research Center, Room 3260 ISR, University of Michigan, P.O. Box 1248, Ann Arbor, \\ MI 48106-1248, USA \\ ${ }^{2}$ School of Economics and Commercial Law, Gothenberg University, Viktoriagatan 30, \\ S-41125 Goteburg, Sweden \\ ${ }^{3}$ Johann Wolfgang Goethe-Universität, Mertonstrasse 17, D-60325 Frankfurt am Main, Germany \\ ${ }^{4}$ CEPS/INSTEAD, Institut Pédagogique, Rue de Diekirch, L-7201 Walferdange, Luxembourg \\ ${ }^{5}$ Statistics Canada, RH Coats BIdg., 24-M, Tunney's Pasture, Ottawa, Ontario, Canada K1A 0T6 \\ ${ }^{6}$ Tilburg University, Department of Social Security Studies, P.O.Box 90153, 5000 LE Tilburg, \\ The Netherlands \\ ${ }^{7}$ The Economic and Social Research Institute, 4 Burlington Rd., Dublin 4, Ireland \\ ${ }^{8}$ Université Nancy II, ADEPS, Faculté de Droit, Sciences Economiques et Gestion, L.A.S.A.R.E., \\ U.R.A. CNRS 1167, 4, rue de la Ravinelle, F-54000 Nancy, France
}

Received July 1, 1991 / Accepted April 4, 1993

\begin{abstract}
Despite very different macroeconomic conditions, demographic structures and degrees of income inequality, favorable income changes among low-income families with children were widespread and strikingly similar across the eight countries in our study. In most European countries, the combination of modest inequality and extensive mobility among the poor enabled virtually all families to avoid relative income deprivation at least occasionally. However, even substantial mobility among the poor in the Unites States could not elevate the living standards of one in seven white and two in five black families to a level that was half that enjoyed by a typical American family.
\end{abstract}

\section{Introduction}

The painful economic problems encountered by Eastern European countries lead all but the most ardent advocates of capitalism to view it with some ambivalence. Although efficient in organizing resources for production and impressive in generating high standards of living, capitalist economies - with unemployment, wage inequality and other problems - threaten the economic well-being of families. When combined with adverse life-cycle events common to nearly all countries - retirement, disability, divorce - the list of potential economic risks

\footnotetext{
* This paper is the result of a collaborative research project sponsored by the Rockefeller Foundation, the Russell Sage Foundation and the European Science Foundation as part of its Network on Household Panel Studies. CEPS/INSTEAD provided substantial in-kind support. Deborah Laren provided excellent research assistance. Jos Berghman, Tim Callan, Bengt-Olof Gert, Peter Gottschalk, Pierre Hausman, Bruno Jeandidier, Kjell Jansson, Stephen Jenkins, Anders Klevmarken, Katherine McFate, Udo Neumann, Willard Rodgers, Gaston Schaber, Tim Smeeding, Daniel Stripinis, Hedwig Vermeulen, Wolfgang Voges and Brendan Whelan provided substantial assistance and advice during the course of the project. An earlier version of the paper was presented at the conference "Poverty and Public Policy" in Paris in January, 1991. The paper was edited by Timothy M. Smeeding, Syracuse University, uisng two anonymous referees.
} 
faced by families in capitalist countries is almost as daunting as the list of benefits provided by their economic systems.

In the absence of redistribution, these risks and opportunities might be expected to generate a great deal of economic turbulence for most families and persistent problems for some. Indeed, turbulence in the form of frequent movements into and out of poverty is precisely the picture painted at the turn of the century by Rowntree (1902) in his classic study of working class families in York, England. Defining poverty as a family income inadequate to secure modest levels of nutrition, shelter and other basic needs, Rowntree fashioned from his data a life-cycle model of family poverty. In it, family income usually exceeded this spartan standard for very young children, young people during the late teenage years when they still lived with their parents and had earnings of their own, and again for people at middle age when career earnings were at their peak. Poverty was prevalent among larger families at the early stages of family life and among the elderly when work was no longer possible and career earnings had been too low to provide savings for retirement. In Rowntree's study, family formation and retirement were the key events thought to produce transitions into and out of poverty.

All modern industrialized countries have developed sophisticated government programs during the 20th century to reduce the adverse financial consequences of labor market and demographic events and establish minimum living standards for poor families. Most combine social insurance against specific labor market events such as unemployment, disability and retirement; social assistance that distributes benefits to low-income families according the their means; and universal benefits like child allowances or tax credits that have weak or no links to income.

Despite the long history of such programs, we know very little about their collective success in mitigating the risks of economic insecurity. Comparative income distribution data from the Luxembourg Income Study show large differences across countries in the incidence of poverty as well as differences within countries in poverty risks as they affect different demographic groups (Smeeding and Rainwater, in press). But it is far from clear that evidence based on annual snapshots of the income distribution, tells us anything about the extent of persistent poverty in the countries in their study.

The correspondence between the distribution of annual and longer-term income depends on the extent of family economic mobility. If a family's economic position is entrenched, with little possibility for upward mobility, then the distribution of short- and long-term economic status will be very similar. But if family incomes are highly volatile and opportunities for upward mobility ample, then a single-year snapshot of the income distribution cannot be trusted to provide an accurate picture of longer-run economic conditions and opportunities.

Longitudinal household data in the United States show frequent, although far from universal, transitions out of poverty, often as the result of economically favorable events such as employment or marriage. For example, the US Census Bureau's Survey of Income and Program Participation found that one-quarter of all individuals living in households with incomes below the United States poverty threshold in 1984 were not poor in 1985 (US Bureau of the Census, 1989). Onequarter of the exits could be linked readily to increased employment, and about one-tenth to marriage. A primary goal of our paper is to assess whether upward economic mobility is as extensive in Canada and European countries as in the United States. 
The structure of our paper is as follows. In Sect. II we describe our sources of data and definitions of poverty. The third section presents our findings on poverty rates and transitions, the duration of poverty spells and events associated with poverty exits and entries. Section 4 summarizes our results and their policy implications.

\section{Data sources and definitions of poverty thresholds}

Our analysis of poverty transitions uses simple transition tables, which compare family income position at two points in time, usually one year apart. The eight countries that have gathered the requisite longitudinal economic information from representative samples of their populations during the 1980s are: Canada, (the Lorraine province of) France, the Federal Republic of Germany (not including former East Germany), Ireland, Luxembourg, the Netherlands, Sweden and the United States. Details on the data sets and procedures are presented in the Appendix. Poverty data from three countries - France (Lorraine), Luxembourg and the Netherlands - should be viewed with caution. Sample sizes are small in the French and Luxembourg panels. With the Dutch data there appears to have been selective attrition among low-income households in several of the early waves.

In brief, and with exceptions noted in the Appendix, the heart of our measure of family economic status is total family income, including social assistance and other government and private transfers, but excluding income and payroll taxes. Samples drawn from all countries consisted of families with minor children.

We defined poverty in two different ways. We call the first "median-income-based poverty thresholds". To obtain them, we used an equivalence scale that gave respective weights of $1.0,0.7$ and 0.5 to the first adult, subsequent adults and children in the family. We then estimated the distribution of size-adjusted family income for the entire population of each country each year. Since medianincome-based poverty lines are relative to each country's own median, the resulting poverty estimates reflect the degree of inequality of the distribution of size-adjusted family income. ${ }^{1}$ We defined a family to be in "median-income-based poverty" if its size-adjusted income was below $50 \%$ of the median in that year. An "escape from median-income-based poverty" is defined as a transition from income below $50 \%$ of the median in a given year to income above $60 \%$ of the median one year later. (We require income to jump at least $20 \%$ in order to avoid the ambiguity associated with transitions involving very small income changes from just below to just above a poverty line.)

A second - "bottom decile" - definition of poverty was based on the same equivalence scale but defined the poverty threshold by the point of the size-adjusted income distribution that divided the bottom $10 \%$ of all families from the top $90 \%$. By definition, a constant percentage of each country's population of families is "bottom decile" poor each year. An "escape from bottom-decile poverty" is defined as a transition from the bottom decile to a point at least $20 \%$ higher than the bottom decile break point.

\footnotetext{
Since our medians are based on estimates of the size-adjusted family income of all individuals in the population (not just individuals living in families), median-income-based poverty thresholds also reflect the comparative status of family and nonfamily households in the population.
} 


\section{Poverty rates and transitions}

\section{Poverty rates}

We begin by showing the incidence of poverty in the various countries in our study (Table 1, column 1). Rates of median-income-based poverty varied widely across countries, with Canada, foreign residents of Germany, Ireland and the United States having double-digit rates, and all continental countries with rates of less than $10 \% .^{2}$ Nearly half of all black families in the United States were poor by this definition, reflecting the much worse economic position of US blacks than whites relative to the median for blacks and whites taken together.

\section{Characteristics of the poor and macroeconomic conditions}

It is reasonable to expect economic mobility of the poor across countries to vary with macroeconomic conditions and the characteristics of poor families that might facilitate or retard transitions into and out of poverty. Certain characteristics of poor families themselves - especially lone-parent status, large family size, and the presence of very young children - might be expected to impede transitions out of poverty. As shown in the first three columns of Table 2, poor families in Ireland have the most members, while US poor families are most likely to be headed by a lone mother. Lone-mother status is also relatively frequent among poor families in Canada and among native Germans, although family sizes are typically small.

Income volatility may mean that some poor families in self-employment situations are in the midst of short spells of financial hardship, but self-employed farmers who are poor may be in persistently marginal conditions. The poor are especially likely to be living on farms in Ireland and Sweden and most likely to be self-employed non-farmers in the Netherlands and in Sweden.

Since crossing a poverty line is generally easiest when a family's income is close to the line, we also show in Table 2 the relative gap between the typical (i.e., median) poor family and the median-income-based poverty line. Here US poor blacks are the most disadvantaged, with median poor black families at $63 \%$ of the poverty line. ${ }^{3}$

2 Where possible, data for the Federal Republic of Germany are presented separately for native Germans and foreign residents (the majority of whom are Turks), while data for the United States are presented separately for blacks and whites. (Both sets of minorities were oversampled in their respective surveys, although weights have been used to calculate unbiased combined national estimates.) We suspect that the nature of poverty experiences of ethnic minorities in most of the other countries of our study deserves separate study, but only in the Federal Republic of Germany and the United States were there sufficient numbers of observations for separate estimates. A problem in comparing foreign residents of Germany with blacks in the US is that blacks retain their social citizenship when they become poor. Foreign residents in Germany who become poor many voluntarily return to their countries of origin or, in some cases when they apply for social assistance in Germany and are not citizens of EC countries, they may be encouraged to leave the country. Such departures may lead to an exclusion of the poorest foreigners from the German sample.

3 The Irish gap is surprisingly small, given the macroeconomic and demographic disadvantages faced by Irish families. However, the social-assistance level for families with unemployed heads is indeed roughly $90 \%$ of the median-income-based poverty line. Not included in our analyses are childless Irish households, which fare much less well under the Irish social insurance and assistance framework. 
Table 1. Poverty rates and transitions out of poverty for families with children

\begin{tabular}{|c|c|c|c|c|c|c|}
\hline \multirow[t]{2}{*}{ Country } & \multicolumn{4}{|c|}{ Using median size-adjusted income } & \multicolumn{2}{|c|}{ Using bottom decile } \\
\hline & $\begin{array}{l}\text { Poverty rate } \\
\text { percent with } \\
\text { income } \\
<50 \% \text { of } \\
\text { median in } t \\
{[\%]}\end{array}$ & $\begin{array}{l}\text { Transitions } \\
\text { percent of } \\
\text { poor becom- } \\
\text { ing nonpoor } \\
\text { (of those with } \\
\text { income } \\
<50 \% \text { of me- } \\
\text { dian in } t \text {, per- } \\
\text { cent with in- } \\
\text { come } \geq 60 \% \\
\text { of median in } \\
t+1 \text { ) }[\%]\end{array}$ & $\begin{array}{l}\text { Transitions } \\
\text { percent of } \\
\text { families near } \\
\text { the line } \\
\text { becoming } \\
\text { nonpoor (of } \\
\text { those with } \\
\text { income } \\
40-50 \% \text { of } \\
\text { median in } t \text {, } \\
\text { percent with } \\
\text { income } \\
\geq 60 \% \text { of me- } \\
\text { dian in } t+1 \text { ) } \\
{[\%]}\end{array}$ & $\begin{array}{l}\text { 3-year } \\
\text { poverty rate } \\
\text { percent of } \\
\text { population } \\
\text { with income } \\
<50 \% \text { of } \\
\text { median in } \\
\text { all } 3 \text { years } \\
\text { of a 3-year } \\
\text { period [0] }\end{array}$ & $\begin{array}{l}\text { Transitions } \\
\text { percent of } \\
\text { poor becom- } \\
\text { ing nonpoor } \\
\text { (of those in } \\
\text { the bottom } \\
\text { decile in } t \text {, } \\
\text { percent with } \\
\text { incomes at } \\
\text { least } 20 \% \\
\text { above bot- } \\
\text { tom decile in } \\
t+1 \text { ) [\%] }\end{array}$ & $\begin{array}{l}\text { Income } \\
\text { change } \\
\text { perentage } \\
\text { change in } \\
\text { income } \\
\text { for typical } \\
\text { (median) } \\
\text { poor } \\
\text { family } \\
{[\%]}\end{array}$ \\
\hline Canada & 17.0 & 12.0 & 23.2 & 11.9 & 26.0 & 20.6 \\
\hline $\begin{array}{l}\text { France- } \\
\text { Lorraine }\end{array}$ & 4.0 & 27.5 & 32.0 & 1.6 & 21.0 & 10.2 \\
\hline \multicolumn{7}{|c|}{ Federal Republic of Germany } \\
\hline $\begin{array}{l}\text { all } \\
\text { German } \\
\text { foreign }\end{array}$ & $\begin{array}{r}7.8 \\
6.7 \\
18.0\end{array}$ & $\begin{array}{l}25.6 \\
26.9 \\
20.0\end{array}$ & $\begin{array}{l}23.9 \\
23.7 \\
23.0\end{array}$ & $\begin{array}{l}1.5 \\
1.4 \\
4.0\end{array}$ & $\begin{array}{l}22.8 \\
24.9 \\
17.1\end{array}$ & $\begin{array}{l}17.9 \\
21.0 \\
11.6\end{array}$ \\
\hline Ireland & 11.0 & 25.2 & 21.8 & na & 26.7 & 21.5 \\
\hline Luxembourg & 4.4 & $26.0^{\mathrm{a}}$ & $28.6^{\mathrm{a}}$ & 0.4 & $14.5^{\mathrm{a}}$ & 10.4 \\
\hline $\begin{array}{l}\text { The } \\
\text { Netherlands }\end{array}$ & 2.7 & 44.4 & 23.1 & 0.4 & 21.3 & 7.5 \\
\hline Sweden & 2.7 & 36.8 & 45.4 & na & 16.2 & 8.5 \\
\hline \multicolumn{7}{|c|}{ United States } \\
\hline all & 20.3 & 13.8 & 22.4 & 14.4 & 22.6 & 15.1 \\
\hline white ${ }^{\mathrm{b}}$ & 15.3 & 17.0 & 24.6 & 9.5 & $29.1(21.1)$ & $22.2(13.5)$ \\
\hline black $^{b}$ & 49.3 & 7.7 & 14.6 & 41.5 & $13.8(41.9)$ & $8.2(39.6)$ \\
\hline
\end{tabular}

As shown in the right half of Table 2, employment conditions underlying possible poverty transitions varied widely across the countries. Ireland was clearly the worst off, with very high rates of unemployment, much of it long-term, coupled with declining employment during the mid-1980s. The Netherlands also had double-digit rates of unemployment and extensive long-term unemployment, but experienced more favorable employment growth during the period. Luxembourg and Sweden enjoyed the lowest rates of unemployment, while the United States and Canada had the most favorable growth in employment during this period. Judging by these labor market measures alone, employment-based transitions out of poverty should be most difficult in Ireland and easiest in Luxembourg and Sweden, and possibly in the United States (at least for whites) and Canada as well. 


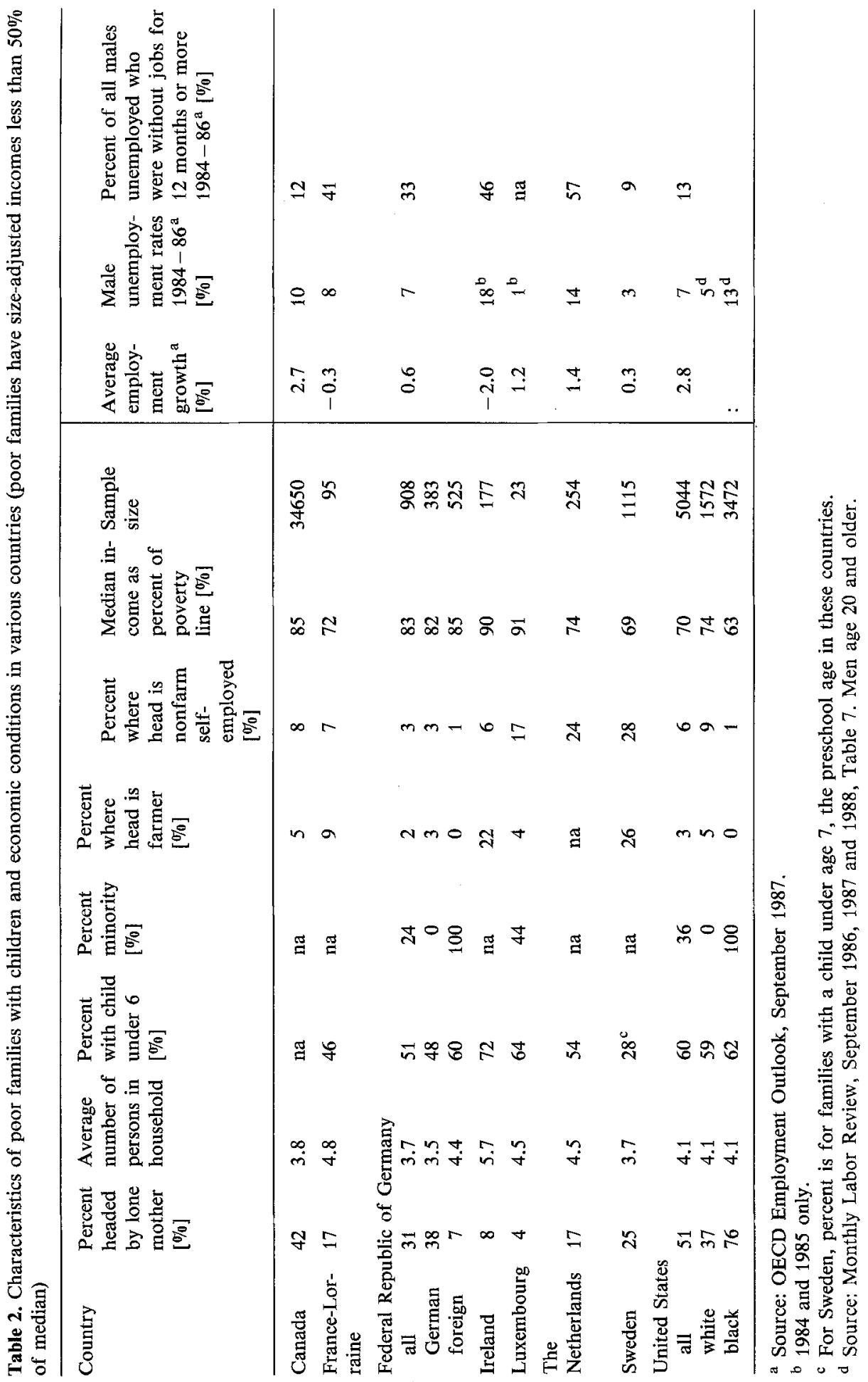




\section{Poverty transitions}

Our findings on transitions out of poverty are shown in the second, third and fifth columns of Table 1; detailed year-to-year transition tables based on the medianincome definition of poverty are presented in Appendix Table 7. Table 1 shows for each country the fraction of poor families in a given year who make the transition out of poverty by the following year.

There are striking differences in the prevalence of transitions out of poverty, ranging from $7.7 \%$ for poor Blacks in the United States to $44.4 \%$ for the Dutch poor. In contrast, escape rates based on the bottom-decile definition of poverty (column 5) are much more uniform. Escape rates for the United States $(22.6 \%)$ are quite high and very similar to those in Canada $(26.0 \%)$, France $(21.0 \%)$, Ireland $(26.7 \%)$ and the Netherlands $(21.3 \%)$ and somewhat higher than in Sweden (at 16.2\%) and Luxembourg (14.5\%). ${ }^{4}$

As shown in the sixth column of Table 1, calculation of the typical percentage change in size-adjusted income between $t$ and $t+1$ among families defined to be "bottom decile poor" in year $t$ also produces fairly similar - and quite positive - results across countries, with the typical bottom-decile poor family experiencing income increases ranging from 8 to $22 \%$.

The seeming inconsistency among the transition-rate results can be resolved by noting the marked inverse relationship between the estimated incidence of poverty and escape rates. Countries with larger fractions of their populations below the poverty line have lower escape rates. In other words, the higher in the distribution of poverty line cuts, the fewer the transitions out of poverty. This is only logical since, everything else the same, the higher the poverty threshold, the farther away the average poor family is from that line and the higher the income increase required to escape poverty.

In the case of the bottom-decile definition, defining the poor to consist of the bottom $10 \%$ of families within each country standardizes the relative size of the poor across countries, with the result that rates of economic mobility across countries become much more uniform (Table 1, column 5).

Another way of standardizing on distance to the poverty line is by calculating transitions rates on the subset of poor families who are close to the poverty line. This is done in the third column of Table 1 . Only families with year $t$ incomes between 40 and $50 \%$ of the median are selected for the analysis, and a transition is defined as having year $t+1$ incomes $60 \%$ of the median or higher. Transition rates among families close to the poverty line are strikingly uniform across the countries, with rates for the United States and Canada being quite similar to those found in Germany, Luxembourg and the Netherlands. Blacks in the United States have lower transitions rates, while Swedes generally have higher-than-average rates.

\section{Longer-run poverty}

Although low-income families in the countries in our study experienced similar changes in income, their very different starting positions - closer to the median

\footnotetext{
4 When the bottom decile is defined on the basis of the incomes of blacks and whites taken together, escape rates for blacks in the United States are relatively low. This is due mainly to the large distance between the typical low-income black family and a poverty line drawn from blacks and whites taken together. When the bottom decile is defined by the black population alone, the escape rate $(41.9 \%)$ is much higher.
} 
in most European countries, far below the median in Canada and, especially, the United States - lead to dramatic differences in the extent to which families are persistently excluded from living standards that are within range of normal.

The fourth column of Table 1 presents poverty estimates using a three-year window. Specifically, the estimates are of the fractions of the populations of the five countries with appropriate data that failed to enjoy incomes at least $50 \%$ of the median in all three of the years. ${ }^{5}$ For the continental European countries France, Germany, Luxembourg and the Netherlands - the combination of modest inequality and extensive mobility among the poor left virtually no families with persistently low relative incomes. However, even substantial mobility among the poor in Canada and the United States left many with incomes that were less than $50 \%$ of the median in all three years. Specifically, about one in eight Canadians, one in seven White American and two in five Black American families were persistently poor over the three years by this definition.

Another useful way of describing the nature of longer-run poverty experiences is with data on the duration of completed spells (i.e., consecutive years of poverty observed from beginning to end). Bane and Ellwood (1986) use Panel Study of Income Dynamics data to calculate the distribution of US poverty spells and find very heterogeneous experiences, with about $60 \%$ of poverty spells lasting one or two years, and only about $14 \%$ lasting 8 or more years. It is important to keep in mind that the estimates of Bane and Ellwood are of single poverty spells, some of which are undoubtedly followed by subsequent spells. Accounting for multiple poverty spells would presumably produce considerably longer lifetime poverty experiences.

Only panels in Canada, the Federal Republic of Germany, the Netherlands and the United States provided sufficiently long-run data to calculate the length of poverty spells. Since these data contain a great deal of information on the length of spells still in progress at the time of the most recent survey wave, we follow the lead of Bane and Ellwood in using event-history methods to construct estimates of the duration of completed spells. ${ }^{6}$ The evidence presented in Table 1 leads to the expectation that many poverty spells in all countries will be of short duration, but spells in Canada and, especially, the United States, are likely to be longer, on average, than spells in either the Federal Republic of Germany or the Netherlands.

The poverty spell data in Table 3 generally confirm these expectations. The median poverty spell lasts less than two years for Germany natives, the Dutch, Canadians and US whites, less than three years for foreign residents of Germany and less than four years for US blacks. By the end of three years, the fraction of poverty spells still in progress is $38 \%$ in Canada, $19 \%$ for German natives, $30 \%$ for foreign residents of Germany, $29 \%$ in the Netherlands, $33 \%$ for US whites and $50 \%$ for US blacks.

\footnotetext{
5 Note that these three-year estimates are not of long-run poverty, since a family poor in, say, the first of the three years could have just ended a very long spell of poverty. Rather, the estimates should be taken for what they are - poverty estimates for each country over a three-year period in the mid-1980s.

6 As is conventional in life-table calculations, our estimates of spell distributions are based on poverty spells begun during the panel period and do not use information on spells in progress at the beginning of the panel period. The latter type of spells are not useful since we had no way of knowing when they began. Information from cases lost to nonresponse during the panel period is used for the hazard-rate calculations up to the point of nonresponse.
} 
Table 3. Duration of poverty speils for families with children

\begin{tabular}{|c|c|c|c|}
\hline Country & & $\begin{array}{l}\text { Number of observations } \\
\text { at start of year }\end{array}$ & $\begin{array}{l}\text { Cumulative survival rate: } \\
\text { percentage of spells still in } \\
\text { progress after } t \text { years }\end{array}$ \\
\hline \multicolumn{4}{|l|}{ Canada } \\
\hline \multirow{3}{*}{ all } & $t=1$ year & 3425 & 63 \\
\hline & 2 years & 1900 & 46 \\
\hline & 3 years & 1225 & 38 \\
\hline \multicolumn{4}{|c|}{ Federal Republic of Germany } \\
\hline \multirow[t]{3}{*}{ all } & $t=1$ year & 339 & 67 \\
\hline & 2 years & 239 & 42 \\
\hline & 3 years & 159 & 22 \\
\hline \multirow[t]{3}{*}{ German } & $t=1$ year & 151 & 66 \\
\hline & 2 years & 97 & 39 \\
\hline & 3 years & 60 & 19 \\
\hline \multirow[t]{3}{*}{ foreign } & $t=1$ year & 188 & 71 \\
\hline & 2 years & 142 & 54 \\
\hline & 3 years & 99 & 30 \\
\hline \multicolumn{4}{|c|}{ The Netherlands } \\
\hline & $t=1$ year & 139 & 54 \\
\hline & 2 years & 46 & 38 \\
\hline & 3 years & 14 & $29^{\mathrm{a}}$ \\
\hline \multicolumn{4}{|c|}{ United States } \\
\hline \multirow{6}{*}{ all } & $t=1$ year & 1295 & 62 \\
\hline & 2 years & 624 & 46 \\
\hline & 3 years & 367 & 37 \\
\hline & 4 years & 213 & 34 \\
\hline & 5 years & 139 & 29 \\
\hline & 6 years & 80 & 26 \\
\hline \multirow[t]{6}{*}{ white } & $t=1$ year & 617 & 58 \\
\hline & 2 years & 262 & 42 \\
\hline & 3 years & 143 & 33 \\
\hline & 4 years & 84 & 30 \\
\hline & 5 years & 50 & 27 \\
\hline & 6 years & 30 & $23^{\mathrm{a}}$ \\
\hline \multirow[t]{6}{*}{ black } & $t=1$ year & 668 & 75 \\
\hline & 2 years & 362 & 61 \\
\hline & 3 years & 224 & 50 \\
\hline & 4 years & 129 & 47 \\
\hline & 5 years & 89 & 37 \\
\hline & 6 years & 50 & 36 \\
\hline
\end{tabular}

${ }^{\text {a }}$ Based on $10-30$ cases.

The remarkably short duration of many poverty experiences should not be taken to indicate that long-run poverty is an insignificant phenomena. The United States data provide the longest window over which to observe the length of poverty spell and they show that relatively few spells ended between three and six years after they began. More than one-fifth of spells for US whites and more than onethird of spells for US blacks are still in progress after six years. Thus a better way of characterizing the spell data is that they show substantial diversity, with a mixture of short and longer-term spells. The extent of longer-run poverty in European 
countries will not be known until the panels run for several more years, but the evidence presented in the fourth column on Table 1 suggests that very few European families will fall into the ranks of the long-term poor.

\section{Events associated with exits}

More direct evidence on whether social and economic processes underlying poverty transitions are similar across countries is provided by linking transitions to demographic and economic events. With varying degrees of comparability, most surveys were able to gauge whether or not the following events occurred at approximately the same time as the poverty transition: a divorce/separation or marriage/remarriage; substantially more or less employment for household members; and the termination or beginning of social insurance benefits.

Table 4 shows the extent to which transitions out of median-income-based poverty could be linked to favorable events - marriage; "job gain", defined as a change from very little to considerable work by family members; "more work", defined as an instance of a major increase in the work hours of an alreadyemployed family; and the beginning of receipt of social insurance benefits. As detailed in Appendix Table 8, the "job gain" and "more work" events are defined to be mutually exclusive, although neither marital nor social insurance events are exclusive of each other or of the employment-based events. ${ }^{7}$ Exits linked to the beginning of social insurance receipt should be regarded less optimistically than exits liked to employment or marriage, since they may result from delays caused by the social-insurance bureaucracy or the receipt of unemployment benefits after only brief periods of work. ${ }^{8}$

The basic results regarding the links between events and poverty exists are readily summarized: employment is by far the most frequent cause of exits; marriage accounts for as many as one-tenth of poverty exits in three countries (Canada, Germany and Sweden): and exits related to social insurance play significant roles in four countries (Canada, Ireland, Sweden and for Blacks in the United States).

\section{Entries into poverty and their associated events}

With the overall incidence of poverty usually changing little from one year to the next, the substantial numbers of families flowing out of poverty implied by our data can be expected to be matched by roughly equal numbers of families falling into poverty. Analogous to Table 1, Table 5 shows the relationship between the fraction of each country's population above the poverty line in year $t$ and the fraction of nonpoor families who were observed to fall into poverty by year $t+1$.

As with poverty exits, there appears to be a decidedly inverse relationship between the fraction of the population at risk of entering poverty and the fraction

\footnotetext{
It is noteworthy that employment-related events in the Canadian data had to be defined on the basis of labor income rather than work hours (see Appendix Table 8). This will probably produce stronger (and possibly somewhat spurious) links to the income-based poverty transitions.

8 In regions of high unemployment in Canada, for example, an individual can receive up to 40 weeks of unemployment benefits after only 10 weeks of work. Thus both insurance- and employmentrelated exits may reflect situations of very temporary employment followed by the receipt of social insurance.
} 
Table 4. Marital and labor market events associated with transitions out of poverty for families with children, using percent of median income

\begin{tabular}{|c|c|c|c|c|c|}
\hline \multirow[t]{2}{*}{ Country } & \multirow[t]{2}{*}{$\begin{array}{l}\text { Number of } \\
\text { observations }\end{array}$} & \multicolumn{4}{|c|}{$\begin{array}{l}\text { Percentage of families escaping poverty } \\
\text { (size-adjusted family income }<50 \% \text { of me- } \\
\text { dian in } t \text { and } \geq 60 \% \text { of median in } t+1 \text { ) ex- } \\
\text { periencing marital and labor market events }\end{array}$} \\
\hline & & $\begin{array}{l}\text { Marriage/ } \\
\text { remarriage }\end{array}$ & $\begin{array}{l}\text { Job } \\
\text { gain }\end{array}$ & $\begin{array}{l}\text { More } \\
\text { work }\end{array}$ & $\begin{array}{l}\text { Social insurance } \\
\text { began }\end{array}$ \\
\hline \multicolumn{6}{|l|}{ Canada } \\
\hline $\begin{array}{l}\text { All families escaping } \\
\text { poverty between } t \text { and } t+1\end{array}$ & 3975 & 13 & 26 & 51 & 18 \\
\hline \multicolumn{6}{|l|}{ France-Lorraine } \\
\hline $\begin{array}{l}\text { All families escaping } \\
\text { poverty between } t \text { and } t+1\end{array}$ & 19 & $0^{\mathrm{a}}$ & $2^{\mathrm{a}}$ & $37^{\mathrm{a}}$ & $7^{\mathrm{a}}$ \\
\hline \multicolumn{6}{|l|}{ Federal Republic of Germany } \\
\hline & 129 & 12 & 26 & 31 & 9 \\
\hline poverty between $t$ and $t+1$ & 58 & 15 & 32 & 29 & 10 \\
\hline $\begin{array}{l}\text { All foreign families escaping } \\
\text { poverty between } t \text { and } t+1\end{array}$ & 71 & 1 & 4 & 39 & 7 \\
\hline \multicolumn{6}{|l|}{ Ireland } \\
\hline $\begin{array}{l}\text { All families escaping } \\
\text { poverty between } t \text { and } t+2\end{array}$ & 35 & 0 & 38 & na & 26 \\
\hline \multicolumn{6}{|l|}{ Luxembourg } \\
\hline $\begin{array}{l}\text { All families escaping } \\
\text { poverty between } t \text { and } t+1\end{array}$ & 13 & $8^{\mathrm{a}}$ & $15^{\mathrm{a}}$ & $31^{\mathrm{a}}$ & $8^{a}$ \\
\hline \multicolumn{6}{|l|}{ The Netherlands } \\
\hline poverty between $t$ and $t+1$ & 53 & 2 & 19 & 13 & 8 \\
\hline \multicolumn{6}{|l|}{ Sweden } \\
\hline $\begin{array}{l}\text { All families escaping } \\
\text { poverty between } t \text { and } t+1\end{array}$ & 304 & 24 & 27 & 33 & 20 \\
\hline \multicolumn{6}{|l|}{ United States } \\
\hline $\begin{array}{l}\text { All families escaping } \\
\text { poverty between } t \text { and } t+1\end{array}$ & 592 & 7 & 12 & 56 & 7 \\
\hline $\begin{array}{l}\text { All white families escaping } \\
\text { poverty between } t \text { and } t+1\end{array}$ & 279 & 7 & 10 & 55 & 5 \\
\hline $\begin{array}{l}\text { All black families escaping } \\
\text { poverty between } t \text { and } t+1\end{array}$ & 313 & 9 & 20 & 59 & 13 \\
\hline
\end{tabular}

${ }^{a}$ Based on $10-30$ cases.

who actually fall below the line. Here, too, there appears to be a simple and intuitive explanation: the greater the fraction of the population above poverty, the greater is the likely distance between the typical nonpoor family and the poverty threshold and the less likely that family is to make the transition.

This conjecture finds mixed support in a calculation presented in the third column of Table 5, which standardizes for distance to the poverty line by calculating a transition rate into poverty only among families near the poverty line. 
Table 5. Transitions into poverty for families with children

\begin{tabular}{|c|c|c|c|}
\hline \multirow[t]{2}{*}{ Country } & \multicolumn{3}{|c|}{ Using median size-adjusted income } \\
\hline & $\begin{array}{l}\text { Rate of nonpoverty } \\
\text { percent with in- } \\
\text { come } \geq 60 \% \text { of } \\
\text { median in } t[\%]\end{array}$ & $\begin{array}{l}\text { Transitions } \\
\text { percent of nonpoor } \\
\text { becoming poor (of } \\
\text { those with income } \\
\geq 60 \% \text { of median } \\
\text { in } t \text {, percent with } \\
\text { income }<50 \% \text { of } \\
\text { median in } t+1 \text { ) } \\
{[\%]}\end{array}$ & $\begin{array}{l}\text { Transitions } \\
\text { percent of near-poor } \\
\text { becoming poor (of } \\
\text { those with income } \\
50-60 \% \text {, of me- } \\
\text { dian in } t \text {, percent } \\
\text { with income }<50 \% \\
\text { of median in } t+1 \text { ) } \\
{[\%]}\end{array}$ \\
\hline Canada & 77.7 & 2.8 & 34.0 \\
\hline France-Lorraine & 89.0 & 2.0 & 24.3 \\
\hline $\begin{array}{l}\text { Federal Republic of Germany } \\
\text { all } \\
\text { German } \\
\text { foreign }\end{array}$ & $\begin{array}{l}83.5 \\
85.6 \\
66.0\end{array}$ & $\begin{array}{l}3.1 \\
2.7 \\
5.9\end{array}$ & $\begin{array}{l}20.7 \\
20.5 \\
18.7\end{array}$ \\
\hline Luxembourg & 90.2 & 1.7 & 25.0 \\
\hline The Netherlands & 92.7 & 2.4 & 17.4 \\
\hline Sweden & 94.3 & 0.7 & 13.8 \\
\hline $\begin{array}{l}\text { United States } \\
\text { all } \\
\text { white } \\
\text { black }\end{array}$ & $\begin{array}{l}72.2 \\
77.5 \\
41.8\end{array}$ & $\begin{array}{r}4.3 \\
3.6 \\
12.0\end{array}$ & $\begin{array}{l}33.3 \\
31.9 \\
37.1\end{array}$ \\
\hline
\end{tabular}

Specifically, only families with year $t$ incomes between 50 and $60 \%$ of the median are selected for the analysis, and a transition is defined as having year $t+1$ incomes $50 \%$ of the median or less. Transitions rates among families close to the poverty line are still somewhat higher in the United States and Canada. As in the other poverty data, Blacks in the United States fare worse in the sense that they have the highest rates of transition into poverty, even after distance to the line has been standardized. If anything, foreign residents of Germany with incomes near the poverty line have lower transition rates into poverty than do German residents.

An examination of the linkages between poverty entries and unfavorable events (Table 6) shows that employment events are clearly the most important correlates of entries into poverty. The combination of either loss of work altogether or a reduction in work accounted for more than half of all poverty entries in Canada, the United States and Luxembourg ${ }^{9}$ and at least one-quarter of entries in all other countries.

Interestingly, divorces and separations figured less prominently in the United States than in almost all other countries. This may seem surprising given the array of income support programs available to divorcing women outside the United States. However, the effects of these programs may be overrated. A detailed examination of income changes surrounding divorce in the United States and the

9 Sample sizes for poverty entries are quite small in Luxembourg, owing to the infrequent occurrence of poverty in that country. 
Table 6. Marital and labor market events associated with transitions into poverty for families with children, using percent of median income

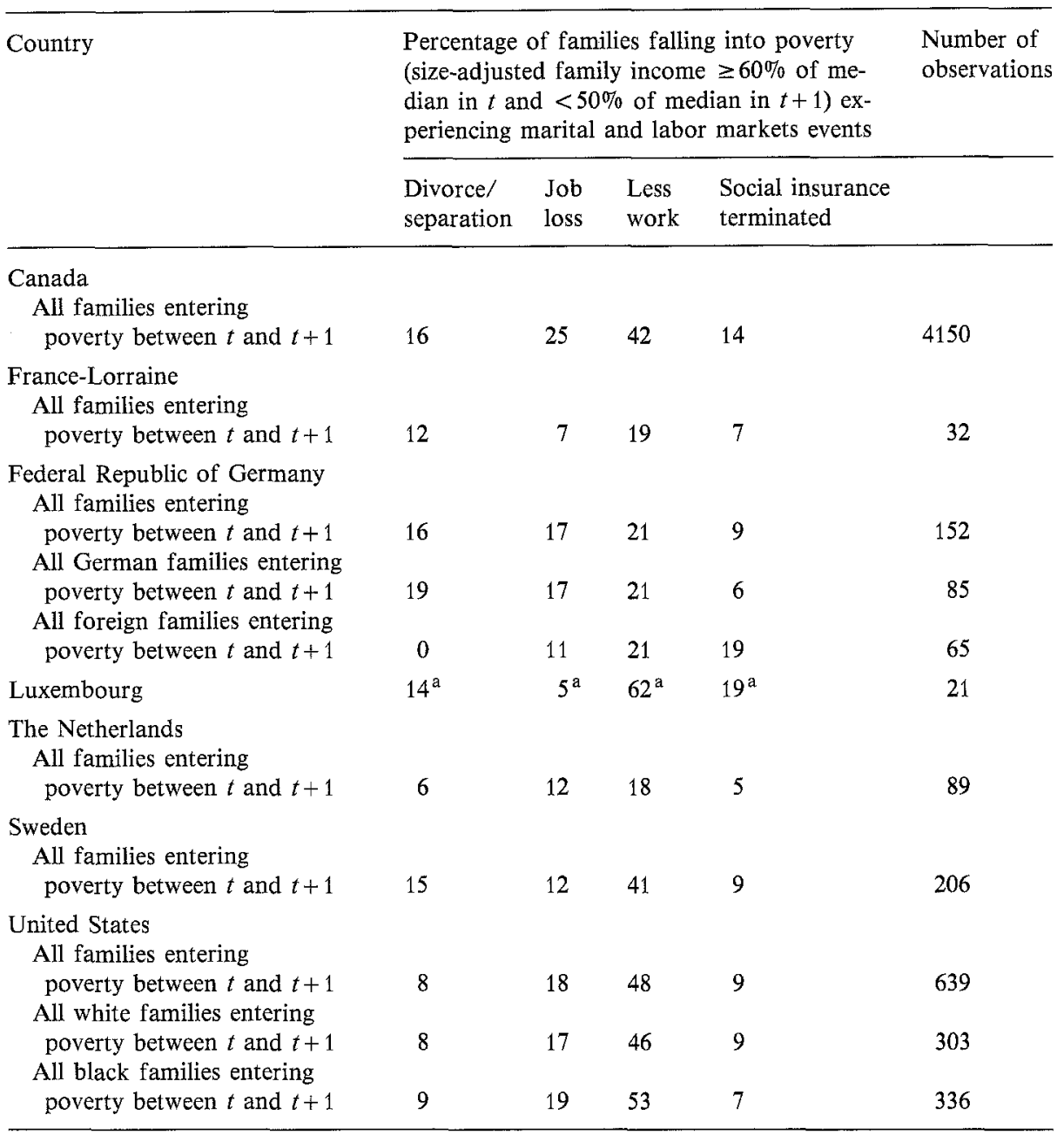

a Based on $10-30$ cases.

Federal Republic of Germany showed very similar patterns (Burkhauser et al. 1990).

The final event, the termination of social insurance benefits, is tied to between 7 and $19 \%$ of the poverty entries. All in all, the picture that emerges from Table 6 is of similarities in poverty-producing events across countries, with employment clearly the most important in all countries.

\section{Summary}

Our basic findings about poverty are easily summarized. The relative economic position of families varies widely across countries with substantial numbers of 
families in the United States and Canada quite badly off. Although favorable income changes among low-income families with children were widespread and quite similar across the eight countries in our study, the very low starting position of the typical poor family in the United States and Canada could not elevate the living standards of substantial numbers of families to a level that was half that enjoyed by a typical Canadian or American family.

Data on the duration of poverty suggest considerable diversity across families. While the typical spell of poverty lasted only one or two years in most countries, other poverty experiences lasted longer. The household panels in Europa have not run long enough to provide reliable estimates of longer-run poverty, but what information has been gathered shows that not all poverty spells can be classified as short-term.

Before delving into the policy distinctions associated with short- and longterm poverty, we begin with a simple but vital point: the best situation is one in which neither kind of poverty exists. Some of the countries in our study did much better than others in minimizing both short- and long-term poverty. In fact, the Luxembourg panel data were not very useful in our poverty-transition analysis because very few families in Luxembourg met any of our definitions of poverty. Despite a considerable influx of foreign workers from poorer EC countries, Luxembourg has combined extremely favorable employment conditions and a safety net of social insurance and assistance programs to reduce (although not eliminate) poverty among its residents. It should serve to remind us of what might be possible in the rest of the countries.

For countries with substantial poverty, our dynamic perspective on the distribution of family income raises new issues in the debate over social insurance and assistance. Above all, the static dichotomy of "poor" versus "not poor" is very misleading and needs to be replaced by at least four dynamic categories of economic position - persistent poverty, transition poverty, the economically vulnerable and the financially secure.

The distinction between persistent and transitory poverty is crucial. Low-income families observd at any given time are really a heterogeneous mixture of families who have fallen into relatively brief periods of poverty and families unable to meet their basic needs for prolonged periods. United States data (e.g., Duncan et al. 1984) and, we suspect, in data from other countries as well, the characteristics of the temporarily poor are not very different from the characteristics of the rest of the population. Relatively few families are immune to the possibility and economic consequences of a bout of unemployment or the departure or death of a spouse. For these families, social assistance can be viewed as a kind of insurance program, available if necessary to cushion them against the severity of their temporary misfortunes. With time, their departure from poverty will again place them in the ranks of the taxpayers, supporting the very social assistance programs that once aided them.

Although surprisingly widespread, movements out of poverty are by no means universal and long-term poverty probably exists in all of the countries in our study. How should social assistance programs deal with the distinction between short- and long-run poverty? For some purposes the temporal dimension is unimportant. Social assistance programs aimed at fulfilling short-term needs - food or heating for example - need not distinguish between the short- and longer-term poor.

However, it is vital that programs aimed at curing long-term poverty make such a distinction, based on knowledge of both who among the poor is most like- 
ly to remain poor as well as who among the long-term poor would profit the most from these programs. It makes little sense to devote scarce resources to provide job training for someone who would have found a job quickly in any case.

A final comment is more general and relates to the structure of economic mobility in the eight capitalist countries included in our study. The widespread (but by no means universal) transitions out of poverty in the United States were first demonstrated nearly twenty years ago (Morgan et al. 1974). One reaction to these results has been that inequality and poverty are the price the United States pays for its dynamic economic system. Surely the data presented here call such an assumption into question. The extent of upward mobility appears to be just as great among the poor in Europe as among US poor. The European countries in our study provide ample evidence that it is possible to combine economic mobility among the poor with only modest inequality, and to leave very few families in a state of persistent deprivation.

\section{Appendix}

Date used in the paper are drawn from a variety of sources and, despite our persistent efforts, retain a number of inconsistencies. In this appendix, we summarize the data sets, procedures and remaining inconsistencies.

\section{Data sources}

Canada: the Longitudinal Administrative Database; Federal Republic of Germany: the Socioeconomic Panel (SOEP); Ireland: a two-wave household panel study conducted by the Economic and Social Research Institute; Luxembourg: the Liewen zu Letzebuerg household panel; France: the Lorraine Household Panel; The Netherlands: the Dutch Socioeconomic Panel Project (SEP); Sweden: the Household Income Survey (HINK); United States: the Panel Study of Income Dynamics.

In brief, and with some exceptions noted below, our poverty analyses took all families with children and classified them in year " $t$ " according to whether their post-tax, post-transfer income was sufficiently low for us to consider them "in poverty". Repeating this procedure in year " $t+1$ " produces a two-way table showing whether or not family income had increased sufficiently for them to be "out of poverty."

All data used in the poverty transition analyses come from longitudinal household surveys, which provide data on changes in the economic status of the same families between years " $t$ " and " $t+1$ ". Calendar years corresponding to " $t$ " and " $t+1$ " vary from survey to survey. For Canada, years " $t$ " and " $t+1$ " consist of four pairs of consecutive years from 1982-83 to 1985-86. For France, years " $t$ " and " $t+1$ " consist of two pairs of years $-1984-85$ and 1985-86. For the Federal Republic of Germany, years " $t$ " and " $t+1$ " consist of three pairs of consecutive years from 1983-1984 to 1985-1986. For Ireland, years " $t$ " and " $t+1$ " are not consecutive and correspond only to 1986 and 1988. In addition, the Irish panel reduced the costs of its second wave by following all Wave 1 poor families but only a random subset of Wave 1 nonpoor families. As a consequence, information on transitions into poverty between the two waves is not available. For Luxembourg, years " $t$ " and " $t+1$ " consist of two pairs of years $-1984-85$ and 
Table 7. Family size-adjusted income transition tables for families with children (using 40,50 and $60 \%$ of median income)

\begin{tabular}{lllll}
\hline $\begin{array}{l}\text { Income as } \% \text { of } \\
\text { median in } t\end{array}$ & \multicolumn{2}{l}{ Income as $\%$ of median in $t+1$} & All \\
\cline { 2 - 5 } & $<40$ & $40-50$ & $50-60$ & $\geq 60$ \\
\hline
\end{tabular}

Canada

(unweighted number of observations $=333342$ )

\begin{tabular}{lrlllc}
\hline$<40$ & 9.3 & 1.1 & 0.7 & 1.1 & 12.2 \\
$40-50$ & 1.2 & 1.4 & 1.2 & 1.0 & 4.8 \\
$50-60$ & 0.8 & 1.0 & 1.3 & 2.2 & 5.3 \\
$\geq 60$ & 1.0 & 1.2 & 2.7 & 72.8 & 77.7 \\
All & 12.3 & 4.7 & 5.9 & 77.1 & $100.0 \%$
\end{tabular}

France-Lorraine

(unweighted number of observations $=1563$ )

\begin{tabular}{llllrc}
\hline$<40$ & 0.4 & 0.4 & 0.4 & 0.3 & 1.5 \\
$40-50$ & 0.6 & 0.9 & 0.2 & 0.8 & 2.5 \\
$50-60$ & 0.5 & 1.2 & 2.3 & 3.0 & 7.0 \\
$\geq 60$ & 0.6 & 1.2 & 4.6 & 82.6 & 89.0 \\
All & 2.1 & 3.7 & 7.5 & 86.7 & $100.0 \%$
\end{tabular}

Federal Republic of Germany - all

(unweighted number of observations $=5725$ )

\begin{tabular}{lllllc}
\hline$<40$ & 1.1 & 0.6 & 0.6 & 0.9 & 3.2 \\
$40-50$ & 0.8 & 1.3 & 1.4 & 1.1 & 4.6 \\
$50-60$ & 0.9 & 0.9 & 3.0 & 3.9 & 8.7 \\
$\geq 60$ & 1.1 & 1.5 & 3.3 & 77.7 & 83.5 \\
All & 3.9 & 4.4 & 8.2 & 83.5 & $100.0 \%$
\end{tabular}

Federal Republic of Germany - German (unweighted number of observations $=3700$ )

\begin{tabular}{lllllc}
\hline$<40$ & 0.9 & 0.5 & 0.6 & 0.9 & 2.9 \\
$40-50$ & 0.5 & 1.1 & 1.2 & 0.9 & 3.8 \\
$50-60$ & 0.8 & 0.8 & 2.5 & 3.6 & 7.8 \\
$\geq 60$ & 1.0 & 1.3 & 3.1 & 80.1 & 85.6 \\
All & 3.3 & 3.7 & 7.5 & 85.5 & $100.0 \%$
\end{tabular}

Federal Republic of Germany - foreign (unweighted number of observations $=1992$ )

\begin{tabular}{lrrrrc}
\hline$<40$ & 3.0 & 1.5 & 0.6 & 0.8 & 5.8 \\
$40-50$ & 3.1 & 3.6 & 2.7 & 2.8 & 12.2 \\
$50-60$ & 0.8 & 2.2 & 6.6 & 6.3 & 16.0 \\
$\geq 60$ & 1.1 & 2.8 & 4.7 & 57.4 & 66.0 \\
All & 7.9 & 10.2 & 14.5 & 67.4 & $100.0 \%$
\end{tabular}

Luxembourg

(unweighted number of observations $=599$ )

\begin{tabular}{llllll}
\hline$<40$ & 0.5 & 0.2 & 0.3 & 0.0 & 1.0 \\
$40-50$ & 0.0 & 0.8 & 1.2 & 0.8 & 2.8 \\
$50-60$ & 0.5 & 1.0 & 2.1 & 2.3 & 6.0 \\
$\geq 60$ & 0.3 & 1.2 & 3.5 & 85.1 & 90.2 \\
All & 1.3 & 3.2 & 7.2 & 88.3 & $100.0 \%$
\end{tabular}


Table 7 (continued)

\begin{tabular}{|c|c|c|c|c|c|}
\hline \multirow{2}{*}{$\begin{array}{l}\text { Income as } \% \text { of } \\
\text { median in } t\end{array}$} & \multicolumn{4}{|c|}{ Income as $\%$ of median in $t+1$} & \multirow[t]{2}{*}{ All } \\
\hline & $<40$ & $40-50$ & $50-60$ & $\geq 60$ & \\
\hline
\end{tabular}

The Netherlands

(unweighted number of observations $=4105$ )

\begin{tabular}{lrlllr}
\hline$<40$ & 0.2 & 0.1 & 0.1 & 0.9 & 1.4 \\
$40-50$ & 0.2 & 0.6 & 0.2 & 0.3 & 1.3 \\
$50-60$ & 0.2 & 0.6 & 1.8 & 2.0 & 4.6 \\
$\geq 60$ & 1.2 & 1.0 & 3.5 & 87.0 & 92.7 \\
All & 1.8 & 2.3 & 5.7 & 90.2 & $100.0 \%$
\end{tabular}

Sweden

(unweighted number of observations $=15326$ )

\begin{tabular}{llllll}
\hline$<40$ & 0.7 & 0.2 & 0.1 & 0.4 & 1.4 \\
$40-50$ & 0.2 & 0.3 & 0.3 & 0.6 & 1.4 \\
$50-60$ & 0.1 & 0.3 & 1.1 & 1.4 & 2.9 \\
$\leq 60$ & 0.3 & 0.4 & 1.4 & 92.2 & 94.3 \\
All & 1.3 & 1.2 & 2.9 & 94.6 & $100.0 \%$
\end{tabular}

United States - all

(unweighted number of observations $=17427$ )

\begin{tabular}{lrrrrr}
\hline$<40$ & 9.7 & 1.8 & 0.8 & 1.3 & 13.6 \\
$40-50$ & 2.1 & 2.0 & 1.1 & 1.5 & 6.7 \\
$50-60$ & 1.1 & 1.4 & 2.1 & 3.0 & 7.5 \\
$\geq 60$ & 1.6 & 1.5 & 3.4 & 65.6 & 72.2 \\
All & 14.5 & 6.6 & 7.4 & 71.4 & $100.0 \%$
\end{tabular}

United States - white

(unweighted number of observations $=10175$ )

\begin{tabular}{lrrrrr}
\hline$<40$ & 6.2 & 1.4 & 0.7 & 1.2 & 9.6 \\
$40-50$ & 1.7 & 1.7 & 1.0 & 1.4 & 5.7 \\
$50-60$ & 1.0 & 1.3 & 2.0 & 2.9 & 7.2 \\
$\geq 60$ & 1.4 & 1.4 & 3.2 & 71.4 & 77.5 \\
All & 10.3 & 5.8 & 7.0 & 77.0 & $100.0 \%$
\end{tabular}

United States - black

(unweighted number of observations $=7252$ )

\begin{tabular}{lrrrrr}
\hline$<40$ & 30.0 & 3.8 & 1.2 & 2.0 & 37.0 \\
$40-50$ & 4.9 & 3.9 & 1.7 & 1.8 & 12.3 \\
$50-60$ & 1.7 & 1.6 & 2.6 & 3.0 & 8.9 \\
$\geq 60$ & 2.7 & 2.3 & 4.6 & 32.1 & 41.8 \\
All & 39.2 & 11.7 & 10.1 & 39.0 & $100.0 \%$ \\
\hline
\end{tabular}

1985-86. For the Netherlands, years " $t$ " and " $t+1$ " consist of three pairs of consecutive years from $1984-85$ to $1986-87$. For Sweden, years " $t$ " and " $t+1$ " consist of 8 pairs of consecutive years from 1980-81 to 1987-88. For the United States, years " $t$ " and " $t+1$ " consist of six pairs of consecutive years from $1980-81$ to $1985-86$.

In all cases the unit of analysis is families with children age 17 or younger at the time of both the year $t$ and year $t+1$ income reports. The family at year $t+1$ 


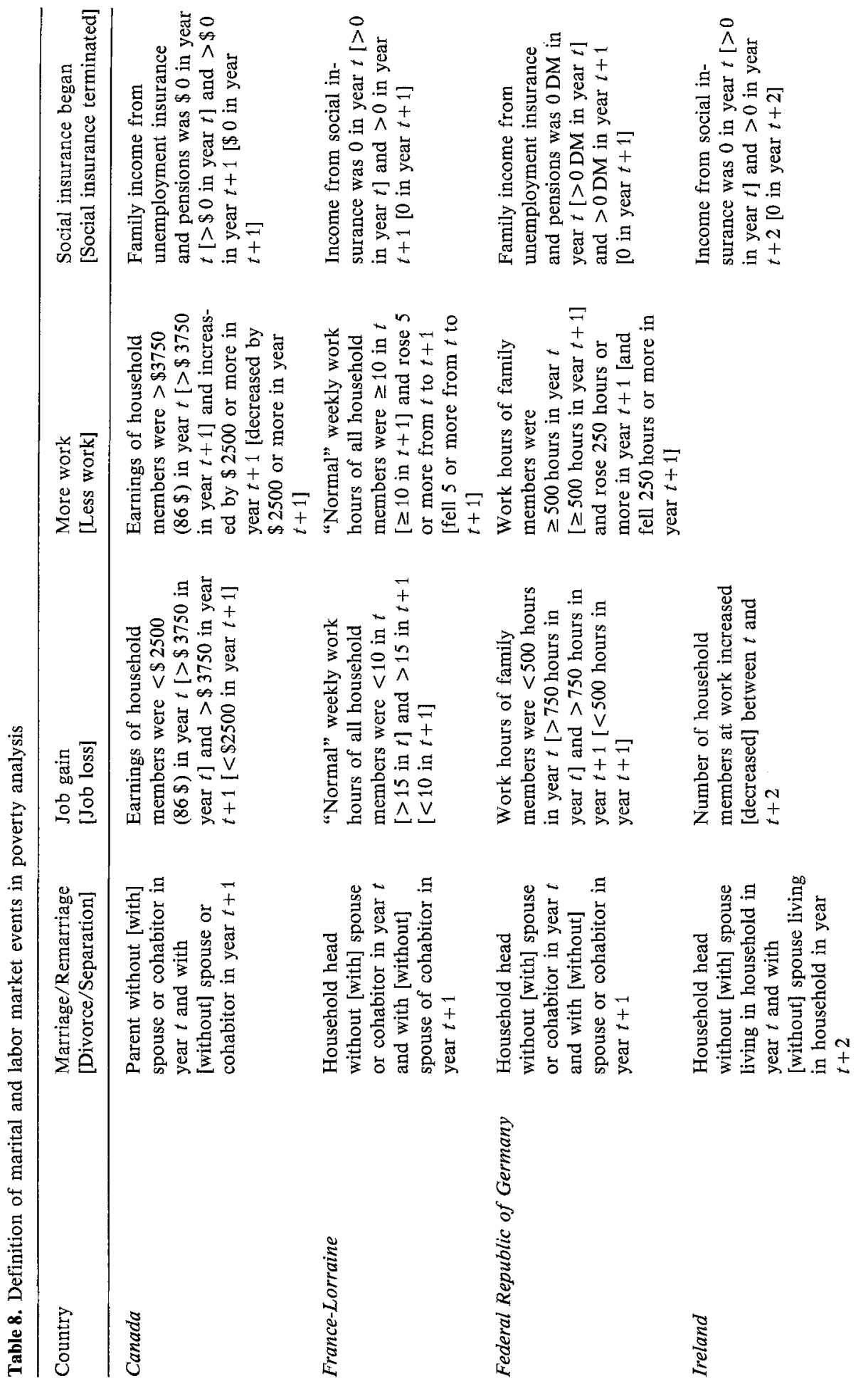




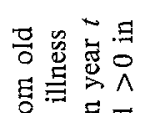

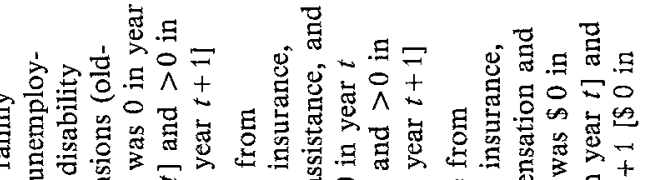

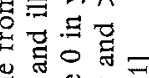

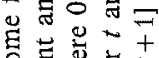

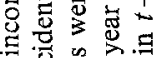

政

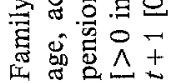

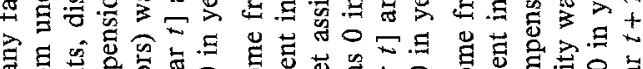

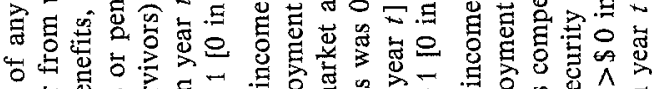

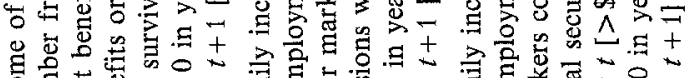

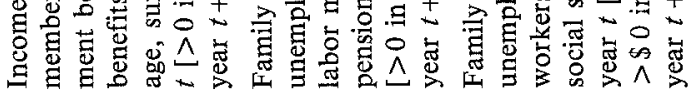

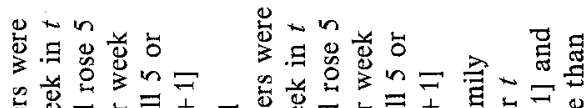

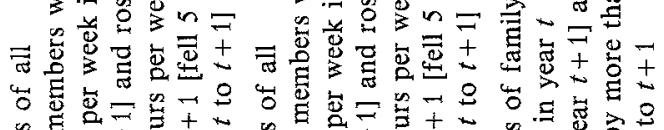

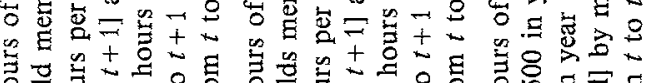

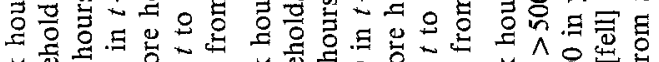

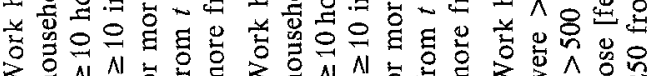

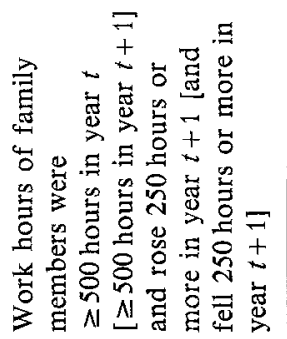

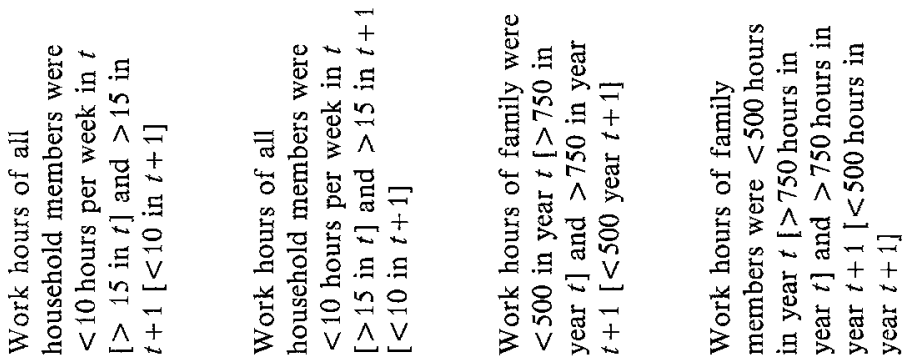

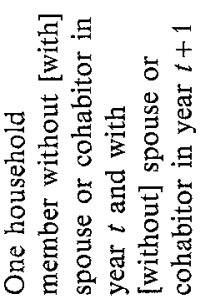
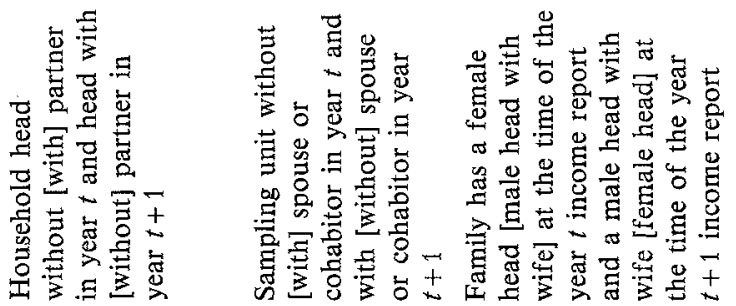
must include at least one of the children and one of the adults present in year $t$ to be kept in the sample. Where the family at year $t$ splits into two or more families at year $t+1$, the family unit in which the youngest child (and one of the adults) remain is kept in our analyses and other derivative families are eliminated.

Income in most cases is annual, post-tax, post-transfer family cash income. Exceptions are the French income data, which are gross of income taxes, and are obtained by multiplying how many of the 12 months prior to the November-December interview a given type of income was received by the amount of such income received in the month prior to the interview; the Dutch data, in which the family income total refers to the household's "normal" income at the time of the October interview; and the United States data, in which the value of Food Stamps, a near-cash transfer program, is counted as part of family income.

To form the median-income-based poverty line, we obtained a median size-adjusted income figure in a given year from our survey data as follows. We: i) took all individuals present in that year as the units of observation (including individuals who were not part of families with children); ii) divided the household income by a family-size adjustment factor, which is the sum of: 1 for the first adult, 0.7 for each additional adult, and 0.5 for each child (under age 18); and iii) assigned that size-adjusted income to each individual in the household. (E.g., each individual in a four-person household containing two adults and two children and a $\$ 20000$ household income has a size-adjusted household income of $\$ 20000 /(1+0.7+0.5+0.5)=\$ 20000 / 2.7=\$ 7407$. $)$ We then: iv) found the (weighted) median of size-adjusted household income of all individuals in the sample; and v) repeated this for each of the years $t$ and $t+1$ used in the poverty analysis. A check to see if the median size-adjusted income changes by a percentage that is comparable to the percentage change in per-capita disposable income and inflation rate was generally reassuring.

Once these medians were calculated, it was a simple matter to categorize our samples of households with children according to whether household income was less than $40 \%, 40-50 \%, 50-60 \%$, or $60 \%$ or more of the median. These four categories, calculated for pairs of $t$ and $t+1$ years, produce the poverty-transition tables that form the heart of our analysis of poverty dynamics.

\section{References}

Bane MJ, Ellwood D (1986) Slipping into and out of poverty: the dynamics of spells. J Human Resources 21 (1):1-23

Burkhauser RV, Duncan GJ, Hauser R, Berntsen R (1990) Economic burdens of marital disruptions: a comparison of the United States and the Federal Republic of Germany. Rev Income Wealth 36 (4):319-333

Duncan GJ, Coe RD, Hill MS, Hoffman SD, Morgan JN (1984) Years of poverty, years of plenty. Institute for Social Research, Ann Arbor, MI

Morgan JN, Dickinson K, Dickinson J, Benus J, Duncan GJ (1974) Five thousand American families - patterns of economic progress, vol. I. Institute for Social Research, Ann Arbor, MI

Rowntree BS (1902) Poverty: a study of town life. MacMillan, London

Smeeding T, Rainwater L (1993) Cross-national trends in income and poverty and dependency: the evidence for young adults in the eighties. In: McFate K (ed) Poverty, inequality and this crisis of social policy: Western states in the new world order. Russell Sage, New York (in press)

US Bureau of the Census (1989) Current population reports, Series P-70, no. 15-RD-1. Transitions in income and poverty status: 1984-1985. Government Printing Office, Washington, DC 